\title{
A Brief Analysis of Innovating and Perfecting the Management Mechanism of College Students' Ideological and Political Education
}

\section{Wei Li Ding}

Zhoukou Normal University, Zhoukou, Henan, 466000

Author profile: Ding Weili, female, January 1984, native of Luyi County, Henan Province, Han Nationality, Zhoukou Normal University, postgraduate, teaching assistant, instructor

Abstract: With the advent of the new era and the continuous implementation of higher education reforms, schools are required to ensure that students' mastery of basic knowledge and professional practice capabilities are effectively improved, and at the same time, they need to promote the orderly development of ideological and political education in order to cultivate responsibility Excellent talents who realize national rejuvenation. This article explores the specific ways of innovating the management mechanism of ideological and political education in colleges and universities from multiple angles, hoping to provide references for other teachers.

Keywords: Educational management; innovative approaches; higher education; ideological and political education.

The rapid economic development and the continuous changes in technology have made different industries and fields require higher standards for talents in the context of the ever-changing era. Not only need candidates have strong professional abilities, but also need to have more complete ideological and political concepts and professional qualities. As the cradle of high-quality talents that cultivates and promotes the country's future development, colleges and universities can organize ideological education and management in an orderly manner so that students can, under the leadership of teachers, complete their own comprehensive capabilities and values. The ability to cultivate outstanding talents that meet the requirements of social positions has become a problem that needs to be addressed by the majority of colleges and universities. Therefore, the author mainly analyzes the three aspects of educational tasks, educational resources, and evaluation, hoping to provide students with a better ideological and political learning environment, so as to grow into high-quality talents that meet the requirements of social development.

\section{Establish an educational management mechanism with educational tasks as the main content}

As the content of ideological and political education is extensive, it mainly takes social education, classroom education, self-education and campus education as the main forms. Therefore, for different educational tasks, teachers need to set targeted teaching tasks to ensure the smooth development of overall ideological and political work . This requires colleges and universities to establish an educational management mechanism with educational tasks as the main content, so that the management of ideological and political education can meet the actual development needs of students while ensuring smooth progress.

Classroom education, as the main base for carrying out overall teaching activities, requires teachers to impart key theoretical knowledge to students and conduct in-depth analysis of their political literacy and ideological value. This will not only enable students to solve practical problems more speculatively under the guidance of teachers, but also ensure the efficient development of learning activities with the encouragement and help of teachers while getting rid of the

Copyright (C) 2020 Wei Li Ding

doi: 10.18282/le.v9i5.1210

This is an open-access article distributed under the terms of the Creative Commons Attribution Non-Commercial License

(http://creativecommons.org/licenses/by-nc/4.0/), which permits unrestricted non-commercial use, distribution, and reproduction in any medium, provided the original work is properly cited. 
influence of negative and negative factors on themselves; For campus education, it mainly focuses on practical content such as dormitory activities, collective activities, and network activities. Therefore, campus education requires a clear division of labor between various departments of the school to ensure that the development of campus education is more conducive to the learning campus atmosphere, so that the overall ideological and political education management work can proceed smoothly; for social education, social practice is the main content, so Schools need to actively connect with local enterprises and cultural education bases, so that students can continuously exercise their own values and behavior awareness through the participation of social practice activities, so as to effectively improve their own ideological and political literacy; self-education is an internal learning factor for students Therefore, the school needs to actively develop psychological education clubs, encourage students to participate in the activities of student unions, organizations, and party organizations to develop a deep understanding of their own situation, and actively accept ideological and political education, so that students can continuously tap their self-worth At the same time, more comprehensive development.

\section{Establish an educational management mechanism with educational resources as the main content}

The content of ideological and political education management is diverse, so schools need to establish an educational management mechanism with educational resources as the main content to ensure the smooth progress of various educational tasks, while effectively combining theoretical education with practical education, so as to complement each other's advantages. In the process of cooperation, ensure the effective improvement of the overall education management mechanism.

On the one hand, the various departments of the school need to actively cooperate. Through the exertion of their own educational functions, they can integrate the overall educational strength of the school, fully excavate educational resources that are beneficial to students' ideological and political education, and ensure the effective teaching content and practical activities rich.

On the one hand, schools need to strengthen the construction of information communication platforms so that teachers and students can communicate in a timely manner. While the feedback efficiency of both parties is improved, teachers can design and manage content more specifically. This not only enables students to ensure the rapid improvement of their ideological and moral qualities in an ideological and political education environment that meets their own learning requirements, but also can grow into high-quality talents that meet the requirements of social development under the correct guidance of teachers.

\section{Establish an education management mechanism with evaluation and assessment as the main content}

A sound evaluation and assessment mechanism can effectively ensure the high-quality development of education management and encourage students to fully mobilize the enthusiasm for learning while achieving the goal of improving the quality of education. Therefore, schools can combine actual conditions to establish a complete evaluation and assessment mechanism, with the main content of students' ideological and political learning effectiveness, learning conditions, activity participation and examination results. At the same time, because ideological and political education has higher requirements for students' comprehensive literacy, schools also need to incorporate students' moral standards, ideological literacy, political attitudes, and theoretical accomplishments into the overall evaluation results. This will not only enable students to improve themselves in a more targeted manner, but also enable students to gain better growth through knowledge learning while training their ideological and political accomplishments. Therefore, a sound evaluation and assessment education management mechanism can promote the overall development of students while ensuring the smooth progress of education.

\section{Concluding remarks}

All in all, as college students, as an important backbone for promoting the long-term prosperity and development of 
the country, colleges and universities must pay attention to the orderly conduct of ideological and political education management. This will not only enable students to grow into high-quality talents that meet the requirements of the development of the times under the guidance of new educational concepts, but also have a higher ideological and political quality while continuously improving their own thinking ability, value concept and ideological and moral level. . Therefore, schools need to combine the current actual education situation and proceed from different perspectives to improve the educational management mechanism, in order to promote the rapid improvement of the level of ideological and political education, and promote the overall development of students.

\section{References}

1. Xiao Mi. An analysis of the path for college counselors to enhance the discourse power of online ideological and political education__ Based on the perspective of supply-side reform[J]. Heilongjiang Education (Theory and Practice), 2020(09): 55-57.

2. Wang Qianqian, Duoji Cidan, Mao Xiaojun. Ideological and political education of college students before joining the party: Taking the School of Plant Science of Tibet Agriculture and Animal Husbandry Institute as an example[J]. Classics of taste, 2020(07): 78-79.

3. Zhao Yan. Research on the impact of college ideological and political education on the cultivation of college student party members [C]. China Global Culture Press, Huajiao Innovation (Beijing) Culture Media Co., Ltd. Proceedings of the 2020 South China Expo Symposium (1) .China Global Culture Press, Huajiao Innovation (Beijing) Culture Media Co., Ltd., 2020: 236-240. 